aldosterone is ineffective in this context (Ross, 1963). The need for high dosage is illustrated in this case during the patient's terminal illness, when $0.4 \mathrm{mg}$ daily proved inadequate in preventing continued hyponatraemia.

\section{Acknowledgments}

We should like to thank Mr D. A. Bailey for permission to report a patient under his care, and Miss C. Ramage, Dr J. D. H. Slater and the Supraregional Assay Service, Middlesex Hospital Medical School, London, for performing the vasopressin radioimmunoassay.

\section{References}

BARTTER, F.C. (1970) The syndrome of inappropriate secretion of antidiuretic hormone. Journal of the Royal College of Physicians of London, 4, 264.

Carter, J.N., Corcoran, J.M., Eastman, C.J. \& Lazarus, L. (1974) The effect of severe chronic illness on thyroid function. Lancet, ii, 971.

Cassileth, P.A. \& Trotman, B.W. (1973) Inappropriate antidiuretic hormone in Hodgkin's disease. American Journal of the Medical Sciences, 265, 233.

De Sousa, R.C. \& JenNy, M. (1964) Hyponatrémie par dilution dans un cas de carcinome pancréatique. Schweizerische Medizinische Wochenschrift, 94, 930.

De Troyez, A. \& Demanet, J-C. (1975) Correction of antidiuresis by demeclocycline. New England Journal of Medicine, 293, 915.

FALCHUK, K.R. (1973) Inappropriate antidiuretic hormonelike syndrome associated with an adrenocortical carcinoma. American Journal of the Medical Sciences, 266, 393.
George, M.J., Capen, C.C. \& Phillips, A.S. (1972) Biosynthesis of vasopressin in vitro and ultrastructure of a bronchogenic carcinoma. Journal of Clinical Investigation, $51,141$.

HaAs, Ch., Rosey, A. \& Choubrac, P. (1975) Carcinome du thymus et syndrome de Schwartz et Bartter. Nouvelle Presse Médicale, 4, 586.

Hantman, D., Rossier, B., Zohlman, R. \& Schrier, R. (1973) Rapid correction of hyponatremia in the syndrome of inappropriate secretion of antidiuretic hormone. Annals of Internal Medicine, 78, 870.

Khokhar, A.M., Ramage, C.M. \& Slater, J.D.H. (1975) Radioimmunoassay of arginine-vasopressin in urine. Journal of Endocrinology, 67, 66 P.

LebacQ, E. \& DelaERC, J. (1965) Hyponatrémie avec dilution plasmatique, par sécrétion inadéquate de vasopressine, dans un cas de tumeur duodénale. Revue Médico-Chirurgicale des Maladies du Foie, 40, 169.

Ross, E.J. (1963) Hyponatraemic syndromes associated with carcinoma of the bronchus. Quarterly Journal of Medicine, 32, 297.

SaCKs, S.A., Rhodes, D.B., Malkasian, D.R. \& RosenBLoom, A.A. (1975) Prostatic carcinoma producing the syndrome of inappropriate secretion of antidiuretic hormone. Urology, 6, 489.

Schwartz, W.B., Bennett, W., Curelop, S. \& Bartter, F.C. (1957) A syndrome of renal sodium loss and hyponatremia probably resulting from inappropriate secretion of antidiuretic hormone. American Journal of Medicine, 23, 529.

Svane, S. (1964) Hypercalcaemia in malignant disease without evidence of bone destruction. A case simulating acute hyperparathyroidism. Acta medica scandinavica, 175, 353.

White, M.G. \& FETNER, C.D. (1975) Treatment of inappropriate secretion of antidiuretic hormone with lithium. New England Journal of Medicine, 292, 390.

\title{
Non-African Burkitt lymphoma presenting as dysphagia
}

\author{
J. R. PitTs \\ B.Sc., M.R.C.P.
}

\author{
A. Cowley \\ M.B., B.S.
}

Department of Medical Oncology, St Bartholomew's/Hackney Hospitals, London

\begin{abstract}
Summary
Cases of non-African Burkitt lymphoma are rare, but the clinical manifestations of this and the African type are similar. The authors believe that this patient is the first described presenting with dysphagia without intrinsic gastrointestinal disease.
\end{abstract}

\section{Case report}

A 38-year-old Caucasian male was referred to the Department of Medical Oncology, Hackney Hospital, London, with a large retroperitoneal mass. He

Correspondence: Dr John Pitts, Department of Medical Oncology, St. Bartholomew's Hospital, London EC1A 7BE. presented with a 1-month history of progressive dysphagia and vomiting, associated with weight-loss of $5 \mathrm{~kg}$. A barium meal showed hold-up at the cardia of the stomach. Oesophagoscopy showed dilatation with debris within; no evidence of malignant disease was seen. At laparotomy, a large lobulated retroperitoneal mass was found, displacing the stomach anteriorly and laterally and compressing the cardia. A biopsy and a gastrostomy were performed and the patient transferred to the authors' unit.

On examination he was thin, not clinically anaemic and there was no lymphadenopathy. There was mild bilateral ankle oedema. Examination of the 
cardiovascular and respiratory systems was normal. The abdomen was soft with a gastrostomy tube in place. There was an impression of a large non-tender epigastric mass, and the liver and spleen were not palpable. The central and peripheral nervous systems were normal.

The following investigations were performed: haemoglobin $11.1 \mathrm{~g} / \mathrm{dl}$; WBC $7.6 \times 10^{\circ} / 1$, with normal film and differential; platelets $394 \times 10^{9} / 1$. Urea and electrolytes normal; ESR $58 \mathrm{~mm} / \mathrm{hr}$; uric acid $0.3 \mathrm{mmol} / 1$; serum bilirubin $10 \mu \mathrm{mol} / 1$; total protein $65 \mathrm{~g} / \mathrm{l}$; albumin $40 \mathrm{~g} / \mathrm{l}$; globulin $25 \mathrm{~g} / 1$; aspartate transaminase 48 i.u./l; alkaline phosphatase 108 i.u./l; IgG $22 \mathrm{~g} / \mathrm{l}$; IgA $2.4 \mathrm{~g} / 1$; IgM $2.4 \mathrm{~g} / 1$; electrophoretic strip normal. Bone marrow aspirate and trephine were normal and the cerebrospinal fluid contained no abnormal cells. A gastrograffin study confirmed that there was no intrinsic gastrointestinal disease.

Review of the original biopsy and a liver biopsy showed the histological and histochemical features of a Burkitt lymphoma (Berard et al., 1969). The Epstein-Barr virus antibody titre was not raised.

The patient was commenced on remission induction chemotherapy with doxorubicin, vincristine, asparaginase and prednisolone. The dysphagia was gradually relieved and within 8 days the patient was swallowing normally. A repeat barium study showed no obstruction to flow, with significant reduction in the extent of gastric displacement. The gastrostomy tube was removed a few days later and the patient remains able to swallow normally with no palpable evidence of disease. On achievement of complete remission, the patient continues on maintenance therapy of mercaptopurine, cyclophosphamide and methotrexate. Intrathecal methotrexate, followed by cranial irradiation, is given in an attempt to prevent central nervous system disease.

\section{Discussion}

Tumours of a histological type identical with that of the African Burkitt lymphoma have been described in Europe and the U.S.A. in both children and adults (Levine et al., 1975). Cases presenting as leukaemia have also been described (Flandrin et al., 1975). The physical pattern of disease appears similar, with involvement of intra-abdominal structures, facial bones or the central nervous system. The disease may be staged as (1) localized involvement of the facial bones; (2) as (1) with cervical lymphadenopathy; (3) abdominal disease; (4) involvement of the central nervous system and/or bone marrow (Arsenau et al., 1975). Intra-abdominal disease in the form of involvement of the stomach, intestines or ovaries appears to be relatively more common in the non-African series. Generalized peripheral lymphadenopathy is rare. Bone marrow involvement is frequently seen early on in the disease, and central nervous system disease is eventually seen in about $50 \%$ of the relapsing cases. The association with the Epstein-Barr virus, which is an important feature of the African disease, does not appear to be significant in the non-African cases (Pagano, Huang and Levine, 1973).

Dramatic responses to cyclophosphamide as single agent chemotherapy have been recorded in both disease types; the more advanced stage seen at presentation in the non-African patients is in accordance with the worse prognosis, hence the justification for more aggressive chemotherapy.

\section{Acknowledgments}

We thank Dr P. F. M. Wrigley, Dr J. S. Malpas and Dr R. Gruchy for permission to report this patient.

\section{References}

Arsenau, J.C., Canellos, G.P., Banks, P.M., Berard, C.W., GralNiCK, H.R. \& DEVITA, V.T. (1975) American Burkitt's lymphoma: a clinicopathologic study of 30 cases. American Journal of Medicine, 58, 314.

Berard, C.W., O'Connor, G.T., Thomas, L.B. \& Torloni, H. (1969) Histopathological definition of Burkitt's tumor. World Health Organization Bulletin, 40, 601.

Flandrin, G., Brouet, J.C., Daniel, M.T. \& Preud'Homme, J.L. (1975) Acute leukemia with Burkitt's tumor cells: a study of six cases with special reference to lymphocyte surface markers. Blood, 45, 183.

Levine, P.H., Cho, B.R., Connolly, R.R., Berard, C.W., O'ConNor, G.T., DORFMAN, R.F., EASTON, J.M. \& DeVita, V.T. (1975) The American Burkitt lymphoma registry: a progress report. Annals of Internal Medicine, 83, 31.

Pagano, J.S., Huang, C.H. \& Levine, P. (1973) Absence of Epstein-Barr viral DNA in American Burkitt's lymphoma. New England Journal of Medicine, 289, 1395. 